\title{
MANAGEMENT ELEMENTS OF THE EMERGENT METROPOLITAN AREAS IN A TRANSITION COUNTRY. ROMANIA, AS CASE STUDY
}

\author{
Ioan IANOŞ, Danie/ PEPTENATU, Cristian DRĂGHICI, \\ Radu Danie/ PINTILII \\ University of Bucharest, Romania
}

\begin{abstract}
Complex processes, specific to the countries in transition, have had major impacts on restructuring the territorial management systems. The removal of restrictions of limiting urban expansion, imposed by the totalitarian regime, has allowed the rapid expansion of cities, beyond administrative boundaries, since 1989. The concept of emerging metropolitan area is explained by the multitude of problems posed by the sketching of these areas and especially by their functioning. Synthesizing, there are presented some managerial experiences considered inchoate, of some emerging Romanian metropolitan areas, with an emphasis on Bucharest's metropolitan area. The conclusions of these descriptive analysis show the complexity of the problems that can occur during the process of building of the metropolitan areas under the circumstances of lack of an inter-municipal cooperation culture. Integrated management takes into account two realities: firstly, that the management of emerging metropolitan areas is trans-scalar, achieving the partial mergence of the management types (including the collegiate one), and secondly, that insuring a multi-level governance without implementing a polycentric intra-metropolitan development policy, is not sufficient.
\end{abstract}

Key Words: emergent metropolitan area, managerial experiences, consensus management, metropolitan governance.

\section{Introduction}

The main objective of this study is to demonstrate the difficulties related to the management of the areas tightly connected to cities in case of the states in the transition process from an excessively centralised economy to the market economy. These spaces are in a structuralfunctional disorder phase, with numerous distortions generated by delays within the institutional construction, as well as the lack of a culture of inter-communal cooperation. The management model of these areas specific to societies in transition, which suddenly changed their political and socio-economic regime, may complete the general management models of the metropolitan areas in a lineal change.

When a culture of inter-communal cooperation lacks, the attitude of each decision factor at local level becomes a break in sustaining the genesis' processes of some coherent metropolitan areas, where the benefits of collaboration are reciprocal. The concrete situation of unsound cooperation within new metropolitan areas of Romania and the experience in promoting the dialogue between the representatives of local communities and of the city, determined us to propose to manage these areas by means of a type of integrated collaboration management, where consensus is the fundamental principle. This type of management may win the reciprocal trust of those who manage each community from the 
metropolitan areas and leaves free space to the display of enterprise spirit (Harvey 1989) in the unfolding of economic, social, cultural activities etc.

\section{A literature synthesis}

The metropolitan area represented an important study subject for the sciences of territorial development during the last decades. The term of emergent metropolitan area was used by Elliot and Perry (1965), who contradicted classical theories regarding the role of the processes of population concentration in the development of new cities and showed that these processes were secondary, reported to the economic processes. Researches demonstrated contradictory processes of structuring/destructuring of metropolitan areas, which took more and more sophisticated spatial shapes. Historical incursion within the metropolitan apparition and development shows a tight connection between this and the dynamics of the production system (Scott 1982). The transition to the fordist economy, where large metropolitan areas were functioning as key elements of mass production towards the post-fordist economy, meant the industry's transfer outside these and the transition to a new type of economy, characterised by a large flexibility. The new cognitive-cultural economy encouraged processes of locational convergence (Scott 2008). Despite the fact distance seems to have disappeared (Hall 1999), digital revolution and telecommunications revolution re-evaluate the importance of geographical proximity in localising the actors who produce knowledge. The effects are visible in the new forms of urbanisation which are registered by such a diverse world at planetary scale, as the urban world.

For the economies in transition from centralised systems to the market economy, it seems that some of the development stages are known by American and West-European economies as skipped or crossed with a very high speed. The impact of the new economy facilitates the almost instantaneous transition from the mass industrial production, extensive, to the new types of activities dominated by the superior tertiary (finances-banks, insurances, IT, research and higher education), by means of which the creative capacities of the employees are valorised. Unlike advanced states, the new types of economic activities revitalize less the town centres and more the suburbs, and especially their metropolitan space, in the countries with an emergent economy (lanoş 2004).

Starting from the case of large cities from Romania, which did not know the classical process of suburbanisation (Nicolae 2002), and being declared closed towns for a few decades, and where economic-social and cultural relationships were dictated from the centre, the accelerated urbanisation around them determined a chaotic expansion of built space (residential, commercial, logistics, IT, productive activities). We are in the phase of structuring some emergent metropolitan areas, areas that the central and local power try to manage (lanoş et al. 2008).

Few studies were written about emergent metropolitan areas of this type. Examples are the studies on some European metropolitan peripheries, published in Beitrage zur Regionalen Geographie (editors: Burdack et al. 2005). There where elements appear in connection to the reconstruction and redefining process of some metropolitan areas around some capitals from Central and Eastern Europe (Berlin, Budapest and Moscow). By analysing the population, economy and restructuring processes, the studies in this volume show the diversity of the suburbs' dynamics of some large cities from this part of Europe. But none of these cities knew excessive interdictions, in the communist period, as Bucharest or the other large cities of Romania suffered. 
The more and more accentuated dynamics of the processes from the urban-rural interface led to a multiplication of preoccupations, both of the researchers and of the decision factors, all of them being preoccupied by a re-thinking of the institutional mechanisms, able to coordinate the functional restructuring of the space around big cities (Brenner N. 2003, 2004). Due to the deficit recorded within work power, raw material and agro-nutritional products, the towns contour a space around them, which provides resources in exchange of services, qualitatively superior to those from the local systems.

In the complex context offered by the present genetic processes of metropolitan areas, the concept of their territorial management must be understood as a continuum of the management types practiced at all organizing and functioning levels. The strategic component of the integrated territorial management has in view the spatial projecting of the interaction between the metropolis and the sustaining area, so that maximum of social-economic benefits for human communities should be accomplished, in the conditions of durable development of those areas (lanoş et al. 2009, Peptenatu et al. 2010, Ogwueleka 2009, Szigethy 2007, Makhelouf 2009, Braghină et al. 2010, Stam et al. 2008). The defining and implementation of integrated territorial management depend on the way the institutional structures cooperate, on the decision factors' professional performance and responsibility, on the cooperation culture from the main administrative units level, and on the partnership established between territorial structures from different hierarchy levels. The integrated management of metropolitan areas represents a multiscale type of decisional interactions, which are guided by operational objectives established by communities, all of them being subordinated to a strategic objective.

In opposition to this type of management, urban governance represents a process of actors, social groups, institutions' coordination, which regards the creation of synergies at different scales, in order to reach some short and medium terms objectives. Each of these actors establish their own objectives, often in doubtful fragmented environments, whereas territorial governance follows the reaching of some collective goals, established without dispute. This process distinguishes itself by the capacity of integrating local interests (belonging to organizations, institutions, social and cultural groups etc) with regional, national or supranational interests, interacting with other specific forms of governing (Hong and Chao-lin 2002).

The approach of territories management frequently appears in the specialised literature, in the context of the analysis of the concepts of governance and governing. Governance, a term used since Antiquity, met multiple connotations along the years. Revitalised in political and social sciences at the beginning of the ' 90 s, the concept of governance is defined as an actor in the governing process, synonym to that of government (Johnston et al. 2000). Recent studies (Pierre 2000, Kjær 2004) refer to two different approaches: on the one hand, the term of governance refers to the organisation type, by the involvement of a series of institutions and actors in the political field, and governing represents one of the many components of governance. In the second case, the term underlines the relationship between these organisations, where governance refers to a particular form of coordination, namely the passing from a hierarchic structuring to the creation / development of networks and partnerships.

Rhodes (1997) considers governance as an inter-organised system of auto-organising and brings in discussion four main traits: interdependence between organisations, the overtaking of the limit between the public, private and voluntary sector; the continuous interaction between the members of a network; confidence and fairness; a certain degree of autonomy towards the state. 
Metropolises, regarded as coordination centres and joints of the interaction networks with a large range, have existed since pre-industrial period, and more obvious in the industrial period. In different times, metropolises adapted their coordination functions depending on the needs of economies and on the technological possibilities (Bourdeau-Lepage, Huriot 2003).

Business services, in general, and advanced services, in particular, have been more associated to central areas of towns. Since in the $X I X^{\text {th }}$ century and most part of the $X X^{\text {th }}$ century the biggest towns as London, New York and Paris confronted a population and production activities' deconcentration, and professional activities of production stayed localised in the business centres' districts. Metropolitan systems have suffered major changes since 1960 , by the deconcentration of production services, not only from central areas towards new developing metropolitan regions, but even from traditional economic nuclei towards intrametropolitan suburbs. Following the first two deconcentration waves which affected population and production activities, specialists recognized a third new wave (Cervero 1989), as well as a new suburbanisation (Stanback 1991).

Metropolization is generally considered to be a double process (Veltz 1996, Stroper 1997, Scott 2001, Bassand 2004). The first process is mainly at world level and it underlines a metropolization process in the economic context of generalised competition. The couple globalisation-metropolization will finally act as an engine behind the important transformations of the modern world. The second process refers to the urbanisation internal structuring process. This process controls the propagation of urbanisation process, leading to the coming out of new territorial specialisations and new centralities. The metropolization process also contains a paradox, with a double movement of population and activities concentration in larger cities. At the same time, it contains an opposed movement, characterised by a population and activities deconcentration. These two phases correspond to two metropolization processes, the first being marked by a general concentration, and the second by a deconcentration in the interior of metropolitan area, with a dissipation from the centre towards suburbs.

In such a conceptual framework, discussing about the structuring and functioning of emergent metropolitan areas, in the transition states, implies fundamenting some management and governance models, adapted to new conditions. The disappearance of the forces of excessive centralisation and the existence of a free market do not represent sufficient conditions to rebuild the relationships urban-rural on a new base. There are other elements, extremely strong, which washout the efforts of real implementation of some management structures able to manage the metropolization processes. From among these, the most important are those which regard: the excessively autonomous behaviour of the decision factors, the lack of an interlocal cooperation culture, the only accidental formation of partnerships, the hegemony tendencies of the big city compared to administrations from the level of rural localities or small towns.

Democracy adds other disturbing elements in the field of interlocal cooperation: the mayors' affiliation to different parties and the sacrifice of community interests in favour of party interests, if the initiatives start from another political area. All these aspects make the management of metropolitan areas be extremely difficult, by processes of free association of main administrative entities. However, the intervention by normative acts, which oblige local communities to a cooperation with the central town, seems outdated and hard to "digest" at local level. That is the reason why it is necessary to re-think cooperation by a collaborative planning, in which all participants at the process of managing a metropolitan area should be considered equal, communicate rationally and freely so that they could find solutions to all interlocal conflicts (Healey 2006). The participation of several actors to taking decisions 
ensures much legitimacy for these decisions. For the implementing and performance of an integrated collaboration management, an important role would be held by re-discussing the concept of "associative pluralism", according to which it is important to assess the conditions in which a multitude of actors can achieve a consensus in the process of territorial management (Habermas J., quoted by Beaumont and Nicholls 2008).

It is obvious that in such a complicated context of managing emergent metropolitan areas in the transition countries, the experiences registered in the developed countries related to local governing, collaboration planning, in the conditions of a participative democracy are very useful. The instauration of such a democracy supposes a certain culture formed in time, or under the pressure of the speed of present changes local communities can take into consideration the actors' pluralism, in order to get an intelligent consensus in starting and implementing some projects. This must admit different opinions and respect the conflict as essential components of the governing process (Melo and Baiocchi 2006).

As metropolitan areas have got specific structures and problems, there are no cvasiuniversal governing models, but only good practices with an indicative character. Like in other processes of territorial development, problems' solving must be based on essential principles of space ethics, able to allow the development of its perennial values (lanoş et al. 2010). At the same time, each state adopts those governing models which it considers to answer best to the problems the urban and rural communities from such an area confront. These models must take into account the special characteristics of each metropolitan area, of the space in which it is inserted, as well as the relationships with political and administrative organisms of the respective state. Moreover, it must take into account that problems which appear in these areas do not have the same character (Foulkes 2008).

The analysis of spatial transformations related to productive reorganizations emphasized that in the last three decades, two elements with spatial impact imposed: one structure - the district, and one process - metropolization. Nicole May (1999) defines the notion of district as a generic term, which expresses different forms of spatial organization of production (commercial districts, industrial districts, localised technological systems districts, innovative environment, technological parks etc). The author tries to individualise the working mechanisms in case of districts, in order to see in what extent these can contribute to the correct and deep understanding of metropolization processes' phenomena.

As regards the metropolization process, Di Ciommo (2001) defines its three dimensions: the demographic tendencies of the agglomeration process, the structure and functionality of economic activities, as well as the institutional-political organization of metropolitan governing. Quoting the analyses done by Bakouche and Damette (1993), the author appreciates them as an efficient instrument in defining the metropolization process. A metropolis/ big city, according to them, is characterised by a large concentration of tertiary activities, specialised commerce, research centres and a high level of services development.

Regarded from the spatial planning point of view (Bassand 1996, Wust et al. 2005), the metropolization of a region is reduced to preferential development of one or two major centres, as well as at the expansion of other towns from the urban network. These metropolitan centres develop cumulative processes, which generate demographic and economic growth, leading to the development of the respective agglomeration. The concentration of technical infrastructures (not always performant), and the excessive growth of resources consuming, inclusively nonregenerative or hardly regenerative (Eriksson 1986) resources constitute real threats for the quality of the urban environment. The severe degradation of natural components make the 
urban ecosystem and the ecosystem associated to this in metropolitan development does not have the capacity of rectifying the basic structures (Pernia 1992).

Jalowiecki (2000) considers the European metropolization process as a process of some towns' catching up the management functions of post-industrial economies, considered at supranational scale. The author enunciates several characteristics of metropolitan towns, and classifies European metropolises in several categories: centres of political decisions, centres specialised in economies' management, capital flows' management, technopoles, cultural and sports centres.

Krätke (2007) considers economic development of European territories as a development's economic potential and innovation capacities' metropolization process. Starting from this, metropolitan regions and urban agglomerations function as engines of the European economy, like integration joints on Europe's world market. The metropolization process is analysed especially referring to the concentration of intensive activities of knowledge economy in the European urban and regional system. A special attention is given to different excellence sectors and to the development paths of European urban agglomerations, by means of the knowledge-based economy, which prevails in metropolitan regions. Metropolization may be also regarded as a selective process (Bourdeau-Lepage 2003), typical for big cities, by which these are better integrated in national or supranational economies.

The dynamics of economic activities from metropolitan areas accentuates itself once again that some administrative structures are organized and are coordinating complex processes which take place in the interface urban-rural. According to METREX (Network of European Metropolitan Regions and Areas), at European level there are approximately 120 metropolitan areas and regions, each of them benefitting from a certain organization structure that is more or less functional.

\section{Methodology}

By definition, the metropolitan area represents a large system of a special complexity, where not only structures are dynamic, but also the field's forces where they develop and complicate. This territorial reality must be managed, and the communities' interest from a metropolitan area must integrate/ include, in a multiscale manner, other communities' interests.

The fundamental work method is that of demonstrating how the experience gathered in building the management systems of emergent metropolitan areas in Romania may lead to the elaboration of a model with extrapolation power for the countries in transition from centralism to market economy.

The defining of the methodology for the integrated collaboration management of metropolitan emergent areas is based on a type of complex management which supposes a multiscale cooperation of communities. It is about integrating several government levels, starting from elementary to metropolitan. The implication of different types of spaces needs an integrated approach for a balanced development and for the interest of all communities.

Integrated collaboration management is based on the knowledge of strategic objectives, as well as the knowledge of decision factors' competences in the field of territorial development, from the basic structures to the structures situated at levels superior to metropolitan areas. Consequently, integrated management is a "compromise” between territorial management of administrative units included in the metropolitan areas, or to which parts of these areas they 
belong to.

Synthetically, the analysis' methodology is based on:

- The description of incipient experiences regarding management, within some emergent metropolitan areas from Romania. This means finding the basic structures which interact in an emergent metropolitan area. Each of these structures has got an individual management system, which takes more or less into account the influences coming from the insertion environment.

- The establishing of the relationships between the institutional constructions of management. The metropolitan area has got its own management system, which in the conditions of inexistence of a structure recognized by law, becomes a type of "consensus management" that can be accepted on variable periods of time, without the guarantee of its persistence.

- The analysis of the decisional flows circulation, taking into account the existence of public and private actors, emergent economies and civil society, on the one hand, as well as of the territorial and sectorial management, on the other hand.

- The individualization of some steps, characteristic for an integrated management in the process of building and functioning of the emergent metropolitan areas.

The tracking of the management model has got an inductive character, starting from the real processes taking place at the level of emergent metropolitan areas. The academic interest is to find the way by which this type of management can be improved, so that it could lead to the spatial defining of the emergent metropolitan areas, and then to their consolidation. In this case, it is important for the management to develop at the same time with the evolution of the real metropolization process and to contain elements of prediction regarding the future structural-functional configuration.

Within the methodological approach, the starting idea is that generally two management systems of metropolitan areas can be considered: one based on exerting the governing by hierarchized decision levels, and the second by polycentric structures. The integrated management implies the cohabitation of the two management structures, ensuring the governing process a maximal efficiency, at the level of metropolitan areas. Moreover, this is situated in the category of a strict management, but opened to a consensus management, which allows dialogue, ensuring the decisions taken at the level of metropolitan areas an increased adapting and flexibility capacity. The proposed collaboration/consensus management is defined as that type of temporary management in which decisions are taken by consensus, and their legitimacy may ensure a pluralist participation to the act of governing.

\section{Management Experiences of Administering Emergent Metropolitan Areas in Romania}

In transition states, like Romania, the management systems of metropolitan areas find themselves in a slow construction process, as there are no local experiences which could be disseminated at national or regional level. In this respect, the metropolization process is in front of the coming out of its control mechanisms, frequently resulting in conflictual phenomena and non-cooperation attitudes. The paradox is that metropolization as a process becomes more and more accelerated and it respects the increase of the intensity and of the structure of territorial cooperation flows around big cities, and the regulations regarding the spatial insertion are fragmentarily adopted, depending on the strictly local and momentary needs of elementary administrative unit. The unitary regulation vision lacks or it exists only in academic environments and less in the decision factors' environment. The attempt of cooperation 
between the territorial decision factors that manage fragments of these metropolitan areas, is more and more consistent, having in view the multiplying of the phenomena of flows' blocking, the difficulty to raise work power stability, the chaotic residential development, the environment issues etc.

In these conditions, the decisions taken at national level are not always encouraging for establishing the metropolitan areas. As an example, by Law 350/2001, the coming out of the metropolitan areas is based exclusively on the local communities' agreement to associate or not the big city nearby. This does not forecast elements able to avoid abuses, generated by the oscillatory and non-constructive option of local decision-makers, which endangers the accomplishing of common objectives for the entire metropolitan area. Even if the local government wants it or not, the process itself of constituting such areas is unfolding, as big cities need an intense cooperation with their insertion environment.

The analyses done upon metropolitan areas from the European Union highlighted the accentuated development, once these territorial structures were set up, following the multiplication of competitiveness advantages created by the association of several administrative units, around some big polarization centres.

\section{A few remarks on emergent metropolitan areas in Romania}

After the year 1995 and especially after the year 2000, when legislation was explicit/ precise in the field of accomplishing the public-private partnerships, pilot studies regarding the establishment of metropolitan areas began. These studies were financed either from central funds (Oradea, Bacău) or from proper funds, especially in the case of municipalities (Bucharest, laşi, Timişoara, Ploieşti).

Today, in Romania there are five metropolitan areas organised according to legislation in force (Constanța, laşi, Oradea, Craiova şi Braşov), and other seven projects of metropolitan areas (Bucureşti, Bacău, Tg. Mureş, Timişoara, Cluj, Ploieşti, Piteşti) (Fig.1).

From the analysis of the way these metropolitan areas were constituted, three main models result (Luncan 2010):

a) the partnership model of local authorities, based on cooperation protocol, accepted and approved by the involved local Councils (of the main town and of small towns and rural communes), with the involvement or not of district council (the superior administrative unit). This type of protocol is centred on the elaboration of the establishment plan of the constituted metropolitan area territory. The fundamental institutional construction is the Council of mayors of all administrative units. With such structures, or close structures, the metropolitan areas Constanța, Craiova and Oradea are functioning.

b) the partnership model of local authorities, based on an organisational form outside local authorities (usually a development agency). The functioning is based on the existence of an administration Council, formed of public and private sector representatives from the metropolitan area. The metropolitan areas laşi and Braşov have got such a structure.

c) the partnership model on a contract basis, implies modifying the administrative limits by partial or total agglomeration of basic administrative units, by law. Such examples do not exist in Romania yet, but there are to be considered in case of the capital's metropolitan area (Bucharest), as there are several bills in this respect. 
The five constituted metropolitan areas established relatively different objectives. Some of them, for example, limited to general objectives, like the alignment at European economic and social standards, the installing of a market climate, aligned to international competitive procedures and the growth of the economic-social cohesion (the metropolitan area Oradea), others defined their objectives explicitly, in a list of 7 or 9 objectives, as it is the case of the metropolitan areas Constanța and, respectively, laşi. The distinction between the objectives of

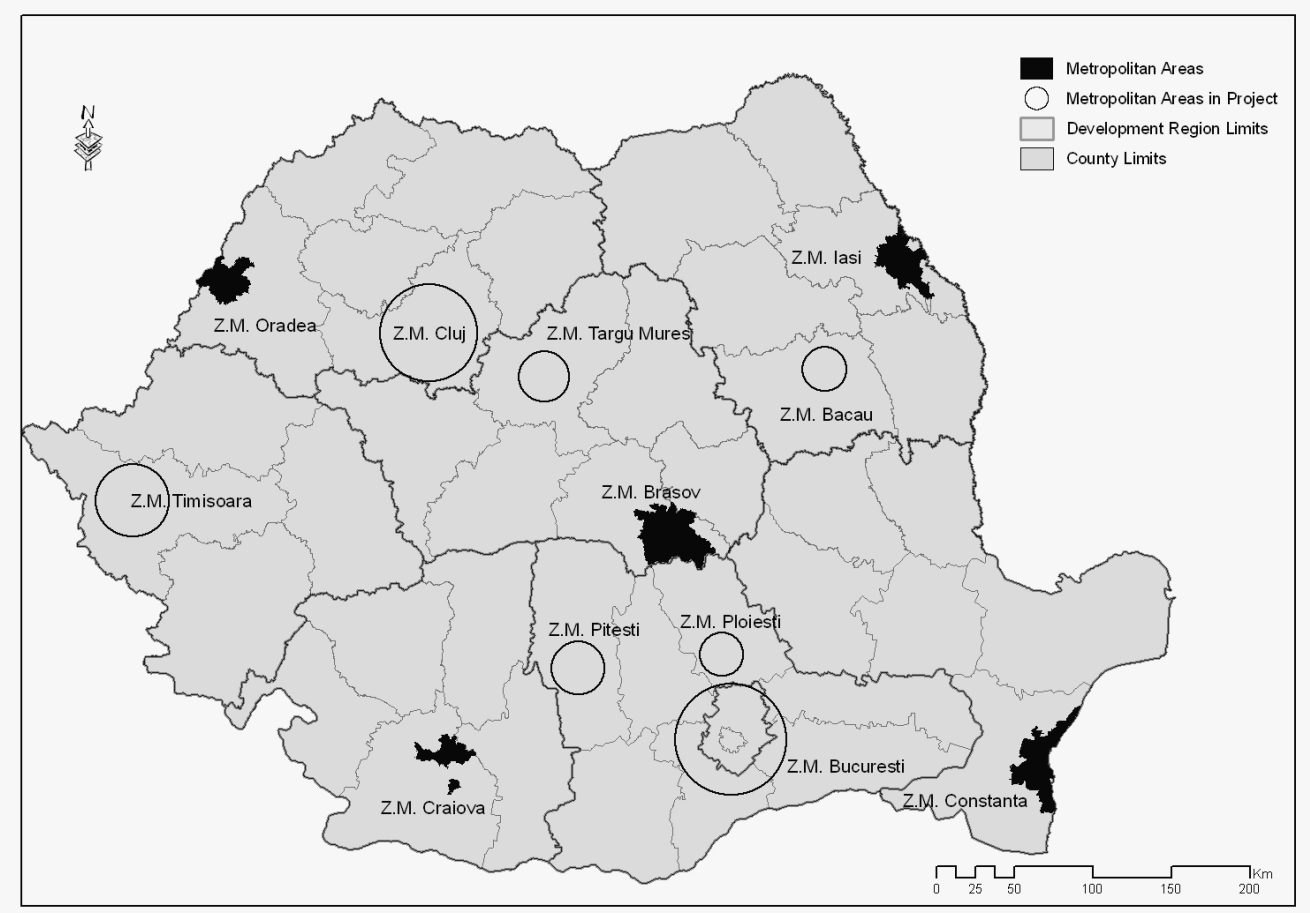

Fig. 1 - Existing or Projected Metropolitan Areas in Romania

the two metropolitan areas is very interesting and demonstrates the difference in terms of vision between the two managing teams (Table 1).

A simple analysis of these objectives leads to the idea that in the case of the metropolitan area Constanța, the objectives are formulated to solve some current problems that the communities are confronted to at present. In the case of the metropolitan area lasi, the objectives envisage perspective goals, trying to target preoccupations towards future. Thus, elements of competitiveness, technological transfer, creative industry promoting, environment quality ensuring etc are meant to prove the present partnership of communities around big city wants to transform this space into an attractive space, at international level. This vision is not retrieved in the case of the Constanța metropolitan area .

The three examples show the big differences existent between the management teams, which do not have the necessary experience and they do not appeal to specialists in order to clearly define the strategic objectives of each of the metropolitan area's formation. 
The emergent metropolitan area of Bucharest, as case study

Although the first studies that try defining the metropolitan area Bucharest began in 1994, the local communities did not succeed up to now to find common elements in order to apply the specialists' recommendations. Though, having in view the explosive development of Romania's capital and its spatial impact, it is considered that we are facing a typical situation of

Strategic Objectives Settled in Two Metropolitan Areas of Cities

Table 1 with Over 300,000 Inhabitants

\begin{tabular}{|c|c|}
\hline \multicolumn{2}{|c|}{ Strategic objectives } \\
\hline Constanța & laşi \\
\hline $\begin{array}{l}\text { Improvement and development of transport, } \\
\text { telecommunications and energy } \\
\text { infrastructures }\end{array}$ & $\begin{array}{l}\text { Increase of economic competitiveness by } \\
\text { creating and developing some structures of } \\
\text { supporting business }\end{array}$ \\
\hline $\begin{array}{l}\text { Development, modernising and improvement } \\
\text { of public services }\end{array}$ & $\begin{array}{l}\text { Technological transfer and promoting new, } \\
\text { creative industries }\end{array}$ \\
\hline Integrated economic development & $\begin{array}{l}\text { Developing territorial connectivity by } \\
\text { ensuring accessibility, improvement of } \\
\text { mobility to and from the growth pole and of } \\
\text { fluidization of the traffic inside it }\end{array}$ \\
\hline The tourism and tertiary sector development & $\begin{array}{l}\text { Improvement of social services by creating, } \\
\text { rehabilitating and modernising the afferent } \\
\text { infrastructure }\end{array}$ \\
\hline $\begin{array}{l}\text { Development of new residential areas, } \\
\text { according to European standards }\end{array}$ & $\begin{array}{l}\text { Exploiting the cultural-historical and natural } \\
\text { patrimony/ heritage }\end{array}$ \\
\hline $\begin{array}{l}\text { Development of human resources, increase } \\
\text { of the occupying rate and control of the social } \\
\text { exclusion and unbalance }\end{array}$ & $\begin{array}{l}\text { Ensuring the environment protection and } \\
\text { quality with the purpose of increasing the life } \\
\text { standard of inhabitants and enhancing the } \\
\text { investment's attractiveness }\end{array}$ \\
\hline $\begin{array}{l}\text { Efficient and integrated managing of the } \\
\text { potential the area disposes of }\end{array}$ & $\begin{array}{l}\text { Promoting territorial cohesion and solving } \\
\text { some common interest problems by creating } \\
\text { and developing partnership structures } \\
\text { between public and private cross-border/ } \\
\text { transnational/ interregional entities }\end{array}$ \\
\hline Elimination of disparities between localities & \\
\hline $\begin{array}{l}\text { Attracting new investments and increasing } \\
\text { the access to resources }\end{array}$ & \\
\hline
\end{tabular}

auto-emergence of a metropolitan area. The metropolization process exists, it amplifies, waiting only to be confirmed by the local authorities.

Alike big cities of the world, Bucharest concentrates an important population volume (over 2 million inhabitants) and economic-social, cultural and political-administrative activities.

Projected in the physical space, these components create a large variety of local forms, which enframe more or less into normal rules of distribution and inter-connection and make some particular structures appear. Multinucleation is the most visible process, by the contouring of 
some knots with very dynamic internal structures (Otopeni, Buftea, Voluntari), tightly connected to the city (Erickson 1986). Here, flows station/ stop in order to transform, to be consumed or redistributed, supposing the permanence of some very varied entrances, as volume and type.

In order to continuously pulse energy (especially informational energy) for ensuring the quality of some internal relationships which should lead to the decrease of gaps which separates it from the European capitals, Bucharest must benefit of a supporting space, a "breathing space". Naturally, during its historical evolution, it created such a supporting space, by processes of auto-organization and permanent rebalance of the exchanges complementary to side/ adjacent area. The current characteristics of this space, if we would not take

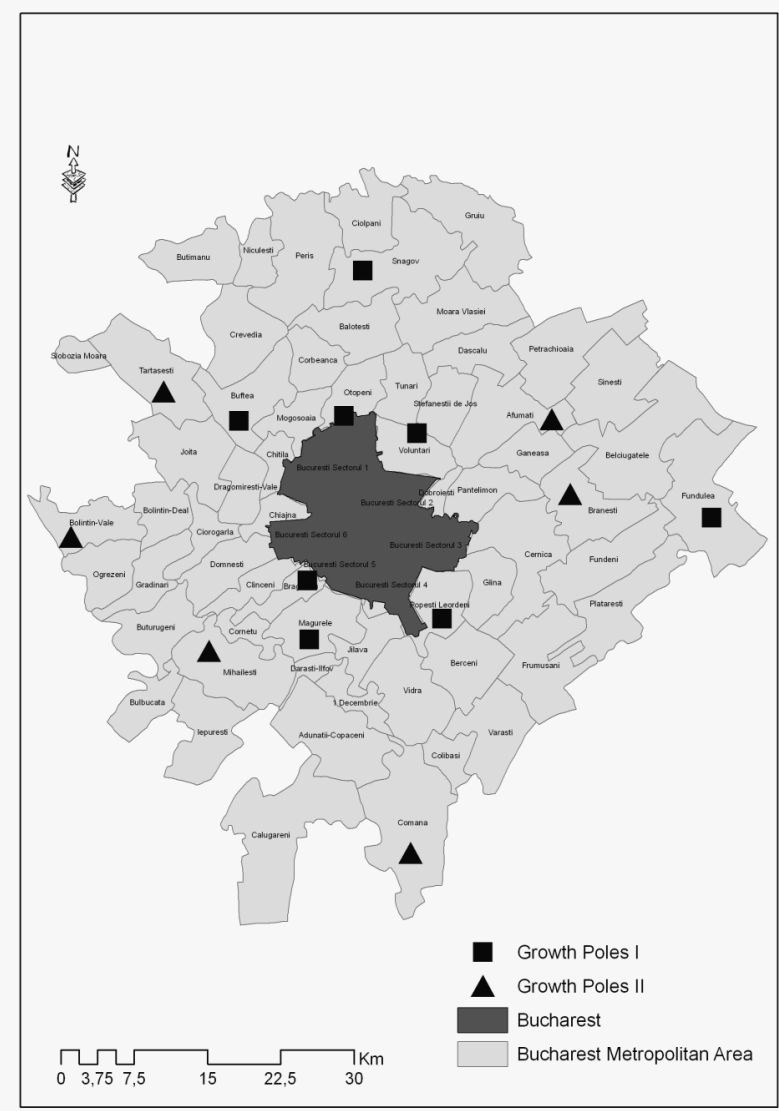
Bucharest into account, do not betray its structure influences. On the contrary, it seems to be a space with a chaotic structure, especially agrarian and with a human capital strongly affected by aging and analphabetism / illiteracy phenomena (Fig 2).

But this space does not have to contour itself chaotically, to block, despite its resistance to change, the flows required by the metropolis, but on the contrary, this space must be flexible, it must receive and react rapidly to the modifications the economical-social and urban restructuring require. In this respect, the contouring of a metropolitan area centred upon Bucharest, able to function as a whole, is considered to be a primary need.

\section{Fig.2 - Bucharest Metropolitan Area}

As a result of its particular evolution, especially in the period 1950-1990, Bucharest has a present structure of sustaining the space which cannot be considered a metropolitan area, but the signs of contouring, under the economy's pressure, demographic growth and improvement of cooperation between administrative units are obvious. In this last remark, the policies of organising the metropolitan space must benefit from a proper institutional framework and resources oriented towards the instauration of a space which is typical for non-discriminating cooperation between all component localities and between these localities and Bucharest.

The dynamics of the metropolitan space from Bucharest should have behind a series of 
processes typical for urbanisation, as suburbanisation, periurbanisation and the clear contouring of the influence area. Or, it is well known in this case we refer to a pseudosuburbanisation, as it was not about a real mass migration of the population with high incomes from the core of city to the adjacent area, so that a real suburban area is created. The demographic growth and the economic development of the communes nearby capital based on their "protection role" within the existence of a close town (as Bucharest was, during the totalitarian regime), respectively on decentralisation, delocation processes, and coming out of some industrial activities. Their industrial functions and the accommodation functions of the migratory population coming from different areas of the country were distinctive for the majority of the settlements nearby capital.

If suburbanisation was not characterised by specific features until 1990, after this year a real process of localising services and individualising some qualitative residential spaces nearby town occur. This tendency will continue in parallel with the intensifying of the interaction between the town and the nearby localities (Erdeli et al. 2000).

At the same time as the atypical suburbanisation, we can speak about a periurbanisation process, not extremely intense, but relatively well structured. The periurbanisation process was extremely attenuated, due to centralised economy, which provided the capital with resources coming from all the country's regions, passing by the state fund. This fact made Bucharest attract especially human resources from the periurban area, but not to contribute to its structuring. The consequence was depopulation, rustication, aging and growth of the analphabetism degree within this area (especially in the western, southern and eastern counties).

As a consequence of this anomaly, it seems rather pretentious to discuss now about a metropolitan area, if we take into account the present situation, but it is extremely necessary to contour and develop in perspective such a space, specific for the big city.

The policies of organising metropolitan space must benefit of a proper institutional framework and resources oriented towards installing a typical non-discriminatory cooperation space between all component localities and between these localities and Bucharest.

Synthetically, following the comparative analyses with other metropolitan areas, compared to the generating town, to the natural, human and economic resources these spaces possess, we consider atypical at least 6 characteristics (lanoş 2004):

1) The increase of population in the suburban space not by the population movement from the proper town, but due to immigration from large distance. The population distribution from the metropolitan area reveals higher densities in the suburban areal and very low densities in the peripheral spaces with more reduced accessibility. These densities were strongly influenced by the urban development strategies promoted along the last half of the century. At the end of the last century's '60s and the beginning of the '70s, besides the pro-natality policy promoted by the former regime, there was decided to be forbidden by law the population coming from other parts of the country, regarding the settlement in the towns with over 100,000 inhabitants. The effect was encouraging for the localities next to Bucharest, as the population from the areas with demographic potential in excess settled in the suburban area, but developed their activity in town. 
2 ) The intense depopulation of the periurban area, by the migration rural-urban, accentuated by the extensive development of the capital's industry. These are characterised by a very high weight of the population over 60 (over $30 \%$ or even over $40 \%$ ).

3) The predominantly agrarian character of the metropolitan area's economy. If previous to the agrarian reform in 1991, Bucharest could function isolated from its agrarian basin, by directly feeding itself from the centralised state fund (constituted by the contribution of numerous agrarian enterprises all over the country, following this event when "the earth returned" in the property of villagers), we assist at the coming out and consolidation of the network of relationships between Bucharest and its surrounding area. At present, the high weight of subsistence agrarian activities, due to reduced surfaces and the lack of a management which could lead agriculture towards urban market, is surprising.

4) The sudden dis-industrialization of Bucharest industry and the slow development of the tertialization process. Concomitantly with this process, de-industrialization was extremely strong, as numerous enterprises diminished their industrial production, they were completely restructured or they were simply closed. The result was the reducing of weight of the population employed in industry, at the capital level, from almost $50 \%$ before 1990 , to approximately $30 \%$ (Cepoiu 2009). Proportionally, tertiary activities developed, and they gradually delocalised in the suburban area, on the main communication roads. After the year 2002, the superior tertiary, especially services for enterprises, finances and banks, insurances, telecommunications and information services, recorded an ascendant evolution, giving back the city functions similar to big European capitals.

5) The excessive administrative fragmentation at the counties and development region level. The past and present administrative organising was extremely unstable, which did not allow the consolidation of some structures that could subsequently adopt attitudes of reciprocal cooperation between the components. At present, this area is fragmented, and it is under the territorial jurisdiction of 5 counties: the Ilfov county entirely, a large part of the counties Giurgiu and Călăraşi, as well as one commune from each of the counties lalomița and Dâmbovița. In such a situation, it is very hard to establish a unitary and lasting cooperation between Bucharest municipality and these territorial entities, each of them with their local or regional interests.

6) The family life standard is among the lowest from the country, despite the fact we refer to the space of the capital. The atypic element of this area comes also from the fact that, even if it contoured around the busiest Romanian urban agglomeration, the metropolitan area is mostly characterised by a very low family life standard. This indicator was calculated taking into account the number of doctors for 1.000 inhabitants, the weight of population that graduated high school out of the total of population, the number of subscriptions for the line telephony, the habitable surface per inhabitant, the infantile mortality, the net/neat migration and the number of illiterate people per 100 inhabitants. However, it is explicable how a capital generated around itself chronic under-development, individualising a real economic and social-cultural desert.

This negative effect explains why for a long period of time, around the capital did not exist any town at less than $50 \mathrm{~km}$. Although very recently there were declared several towns (in the last 8 years, suburban localities have become towns), still these do not have a marking role in the diffusion of the characteristics of an urban life in the territory. 


\section{Model of Integrated Collaborative Management in the Emergent Metropolitan Areas}

Having in view the dynamic and incipient experiences of managing emergent areas from Romania, but also the characteristics of the metropolization process widely presented in the case of Bucharest, we can individualise an integrated management model of them.

This model starts from the idea of adopting a coherent strategy, which could lead to policies with direct effects in the harmonization of the relationships metropolis - metropolitan space. For this, the following issues must be considered:

a) efficient exploitation of the existing legislative framework for promoting some partnership relationships between big cities and their metropolitan space. In this context, it stands out the Law regarding local budgets and the law regarding regional development, both of them with concrete possibilities of sustaining / supporting the consolidation of cooperation between the two distinct territorial entities: the metropolis and the metropolitan area itself. If the first law creates, by the direct allocation to the local budget of a volume resulted from taxes and contributions, ensuring a part of the development resources, the second law can facilitate interregional cooperation with beneficent effects for much larger spaces. The institutional framework established for the implementing of the regional development policy may constitute a brake/ barrier in the cooperation between the metropolitan space and the capital, in some situations. For example, the region Bucharest limits to the town itself and the llfov county, which represents only a part of the metropolitan space. In these conditions, the expansion of cooperation at the level of the entire metropolitan space implies an interregional cooperation, which finally may be more productive, in the situation of some resources and interests which exceed the supralocal and regional framework. However, the actors and factors responsible for applying the regional development policy within this space must be aware that only by the increase of the capital's attractiveness and its supporting space, these may become competitive, at national and international level, in attracting investors, who, in their turn, will induce development in regional spaces globally.

b) the improvement of legislative framework by supporting some bills, which could replenish the impact force upon the consolidation of emergent metropolitan areas. In this respect, proposals detach, as they can be taken into account by the law giver, related to the direct access to advantageous credits, in the conditions of economic abandoning of some metropolitan spaces, development of small and medium-sized enterprises, improvement of regional development laws and under-privileged areas etc.

c) proposing new laws, among which those regarding local development, the limits of interlocal and interregional cooperation, the agriculture and small and medium-sized enterprises' revitalising could detach.

First and foremost, the organization of metropolitan space supposes that, instead of chaotic cooperation between metropolis and its supporting space, a flexible system of relationships to be built, for the benefit of both entities and which could better exploit the metropolises' trumps, at national, regional and continental scale.

In emphasizing the metropolitan emergence process in Romania, the new policies promoted at national and European level regarding polycentric development are considered. By government decision, there were established, outside the capital, 7 national growth poles, as well as 12 urban growth poles (the Government Decisions 998 and 1948 from the year 2008) (Fig.3). The 
national selected poles have all the chances to contour the viable metropolitan areas, which could support metropolises in their affirmation, both at national and European level.

In building the management system that can ensure efficiency to the metropolitan governance, one must start from the way local and sectorial territorial governances interact. In the concrete

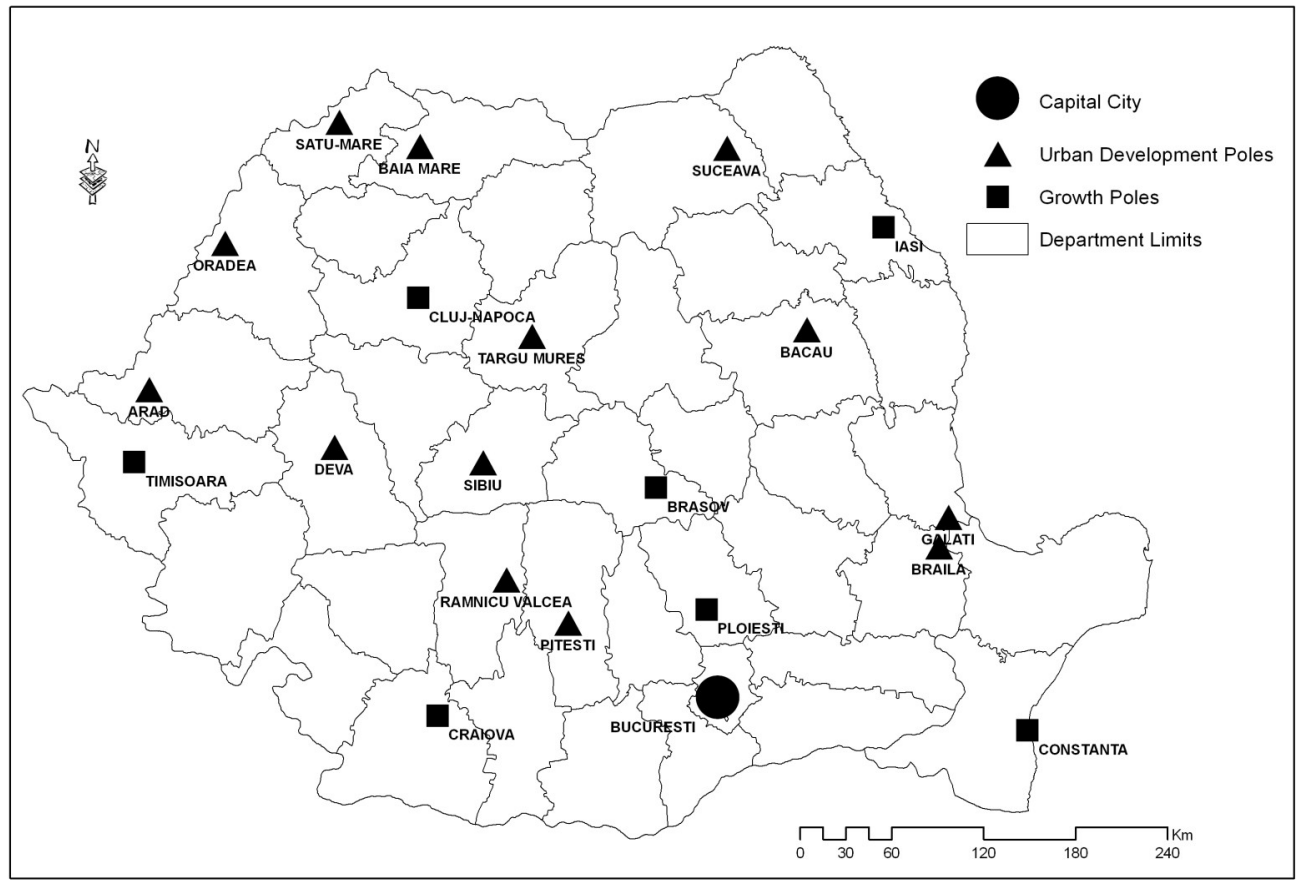

Fig.3 - Development Poles Network, According 998/2008 Government Decision

case of emergent metropolitan areas, metropolitan governance tends towards performance if it has in view the supporting elements and the network of relationships between them. As it results from Fig.4, the main generic components of an emergent metropolitan governance are represented by the state, metropolis and urban and rural communities, emergent economy and the maturing of civil society (Knieling 2009).

In case of the conditions of emergent metropolitan areas, the state has got an important role, as it may offer some facilities prior to these spaces and it may support the accomplishing of some public-private partnerships, which can contribute to the sustaining of emergent economic branches. State may also interfere in sustaining the cooperation relationships between metropolis and urban and rural communities from the metropolitan area, by adopting a flexible legislation in the field. According to the legislation in force, the 7 national growth poles will attract approximately $50 \%$ from the funds allocated to Romania by the EU, and the other 12 , approximately $20 \%$ (the Government Decision nr. 998/2008).

It is obvious that the important role is that of metropolis and local communities (urban and rural), which take part, by voluntary association, to the carrying out of an attractive metropolitan 
Ioan IANOŞ, Danie/ PEPTENATU, Cristian DRĂGHICI, Radu Danie/ PINTILII

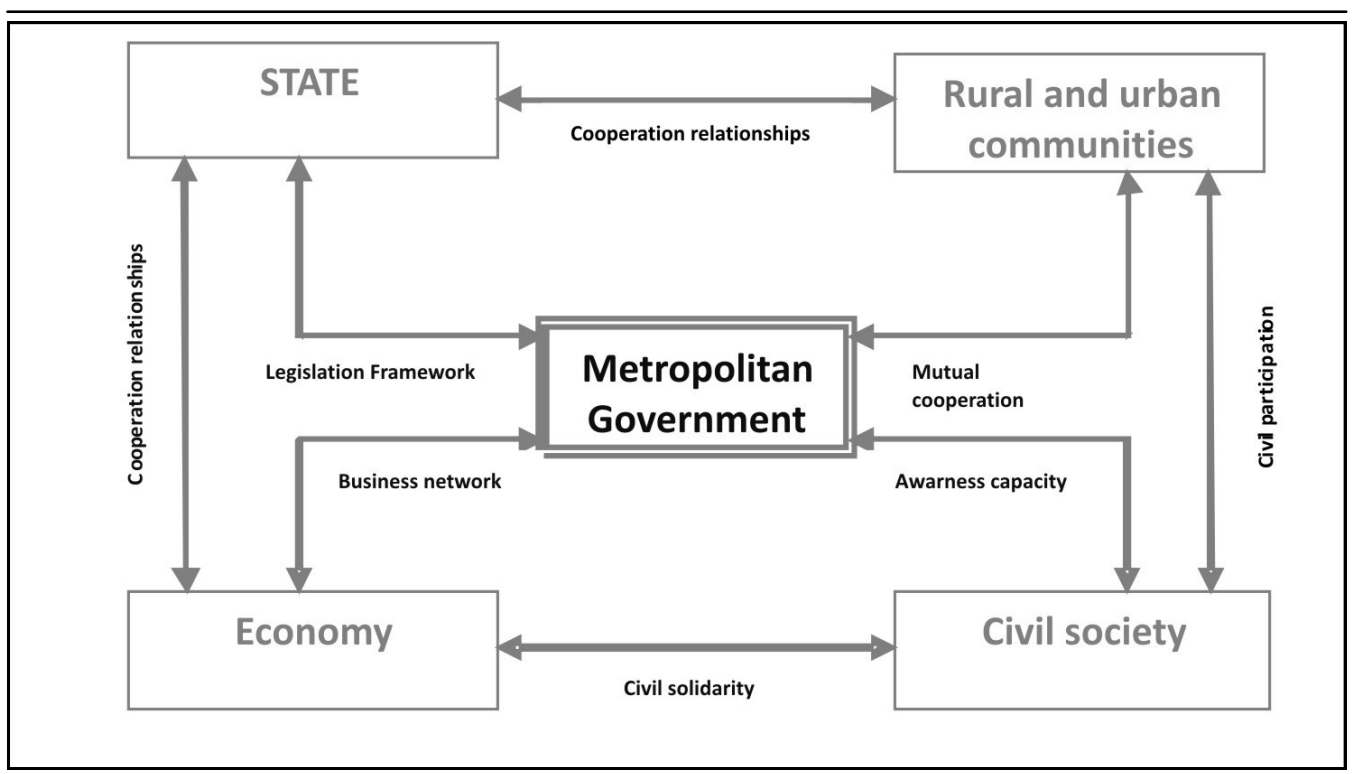

Fig. 4 - Premises for the Emergent Metropolitan Integrated Management

(Knieling 2009, modified)

area, characterised by a certain coherence and economic-social solidarity. The persistence of these intercommunal cooperation relationships is essential in the perspective of accomplishing an efficient governing at metropolitan level. Moreover, the conscious concern of all communitary actors for the projects' accomplishing becomes a necessity in the governance permanence, despite the potentially different option of some local leaders.

The success of the metropolitan governing depends in a large extent on the economic growth. Or, an emergent economy, characterised by branches which multiply initial investments and have got effects generalised at the level of metropolitan area cannot but sustain a certain type of metropolitan governance. Economic growth takes place by the relaunch of the public-private type partnerships, by creating and sustaining some economic actors' networks, able to exploit the strong points which arise from the establishing of such a cooperation space.

Civil society is important within all this structure, bringing more consistency in the favour of social-economic, cultural but also mental cohesion. The actions of civil society envisage the attraction of economic actors in the field of civic solidarity, people and local decision factors' awareness for the advantages of a direct cooperation for everybody's use. The promoting of the participative democracy, in total respect regarding community and space, fundamentally contributes to the implementing of the durable metropolitan development policies.

Governing in the emergent metropolitan areas implies more than a success model exactly transposed from developed countries to a transition country. Such a governing has got its own evolution, being correlated step by step with other processes related to: economic restructuring and transformation, democratization of relationships between human communities, instauration of a certain respect towards ecological limits of space, changing of mentality towards the act of governing etc. 
The importance of an efficient management of the relationship between big cities and subordinated space is underlined by the numerous studies showing that the most competitive regions have got the most competitive towns, too. Once the metropolitan integration process is emphasized, it becomes more and more obvious a governing system by which the transfer of responsibilities between communities is assumed and supported. This transfer is accompanied by a decentralisation towards the inferior decision levels specific to each metropolitan area. The analogy is based on the studies regarding European integration launched by some authors, which sustain the necessity of this transfer between the states and EU organisms (Pollack 1994, Hooghe and Marks 2002).

The effects determined by metropolitan increase upon space are obvious: the changing of the way of using the lands, the reducing of forest surfaces and natural habitats by the aggression of residential, industrial and service oriented constructions, the increase of the traffic and the impossibility to promote a policy of sustainable development. Solving these problems imply the instauration of some instruments of spatial management, as Urban Growth Boundaries (UGB), by means of which it is tried to control the sprawl process by systematizing growth (Carlson and Dierwechter 2007)

For an efficient governing in the emergent metropolitan areas, it is necessary to build a management system which can combine the management centred on hierarchized decisional levels (Chiriac 2009) with territorial management by polycentric structures. Taking into account the particularity of emergent metropolitan areas, the emphasizing of the type of management on hierarchized levels (multi-level) may discourage the participation into cooperation. From this point of view, there are already signals regarding the metropolitan area lasi, where, by the statute, it was established that the President of Metropolitan Council is the metropolis' mayor.

The new mayors elected in some communes analyse the possibility of contesting the total subordination of the metropolitan area's decisional mechanism, to the metropolis' mayor. Due to this aspect, finding a cooperation solution at the level of metropolitan area by an integrated management, of consensus type, including polycetricity elements, seems the most credible.

Starting from these premises and taking into account other countries' experience in elaborating an intrametropolitan cooperation policy and its implementation, we consider that the integrated management system of emergent metropolitan areas must be centred upon an independent institutional construction. This management system has got different characteristics in relation to constitution stages of emergent metropolitan areas. Up to a point, this can be identified, inclusively in already built metropolitan areas (which face big disfunctionalities in the process of decisions implementing), with the following steps:

a) Establishing confidence between dialogue partners. This supposes that, at the initiative of a group of mayors, among which the metropolis' mayor may be the main engine, one or several meetings are established. There is to be discussed the necessity of such a preoccupation, to be established a cooperation strategy and to be expressed the agreement regarding the institutional construction which is to be achieved;

b) Accepting the general cooperation strategy and establishing the policies in this respect. In these conditions, a Charter of metropolitan cooperation will be elaborated, including institutional structures and the instruments of creating the cooperation and functioning framework of metropolitan areas. After its approval, the next steps will be the following ; 
c) Instituting the Metropolitan Cooperation Council. This represents an extremely important step, establishing the existence of a semi-official territorial structure. Having in view its competences, this Council will focus its entire cooperation activity at the level of metropolitan space;

d) Building the Metropolitan Cooperation Agency. Taking into account the metropolitan space heterogeneousness, the multitude of component communes and the big discrepancy between the capital and other local communities, this task will be extremely difficult. With diplomacy and reciprocal understanding, starting from the idea of the respect towards the smallest local communities, beneficent compromises can be done, satisfactory for all partners;

e) Establishing the Metropolitan Cooperation Fund. The limited resources at local level and the serious problems each of these communities confront with will constitute restrictive elements in ensuring a proper volume;

f) Elaborating a Metropolitan Cooperation Programme on short, medium and long term. The Metropolitan Cooperation Agency will be responsible for preparing this programme, which will have to prove a strong enterprise spirit, too;

g) Implementation of the Metropolitan Cooperation Programme. The selection of the great interest projects for as many local communities as possible will be taken into account, so that local communities directly notice the advantages of such a new approach of partnership relationships; moreover, flexibility in the implementing process is a condition of its accomplishment compliant to the rapid changes that appear at city level.

h) Monitoring the Metropolitan Cooperation Programme. The attentive supervision of the way in which financial funds and different types resources are used, constitutes an important task that ensures the partners' protection and confidence;

i) The annual evaluation of the Metropolitan Cooperation Programme efficiency. Every year, a report will be drafted, report that the Metropolitan Cooperation Council will bring into the attention of all local communities' representatives who will appreciate, the activity of this cooperation coordination organism;

j) Proposals regarding the improvement of the Metropolitan Cooperation Council's activity. Following the periodical analyses, the experience of other similar organisms of territorial coordination of the activities of economic-social development, this council may decide its reorganisation, inclusively the improvement of institutional framework.

The track of these steps must lead to an efficient integrated management of the emergent metropolitan areas. In this respect, the main characteristics of the management model result from a compromise between all management systems regarding spaces that are totally or partially enframe in metropolitan areas (Fig.5). In the lump, local management, rural and urban communities management, the management of the associations between them, as well as metropolis' management are enframed in the metropolitan management system.

In this vision, local management, the management of rural, urban communities, of the associations between them, as well as city management integrate in a system of metropolitan collaboration management. Partially, in the metropolitan area, management systems characteristic for counties and development regions are identified. Practically, at the level of the emergent metropolitan area, the management system includes local actors, interested in 


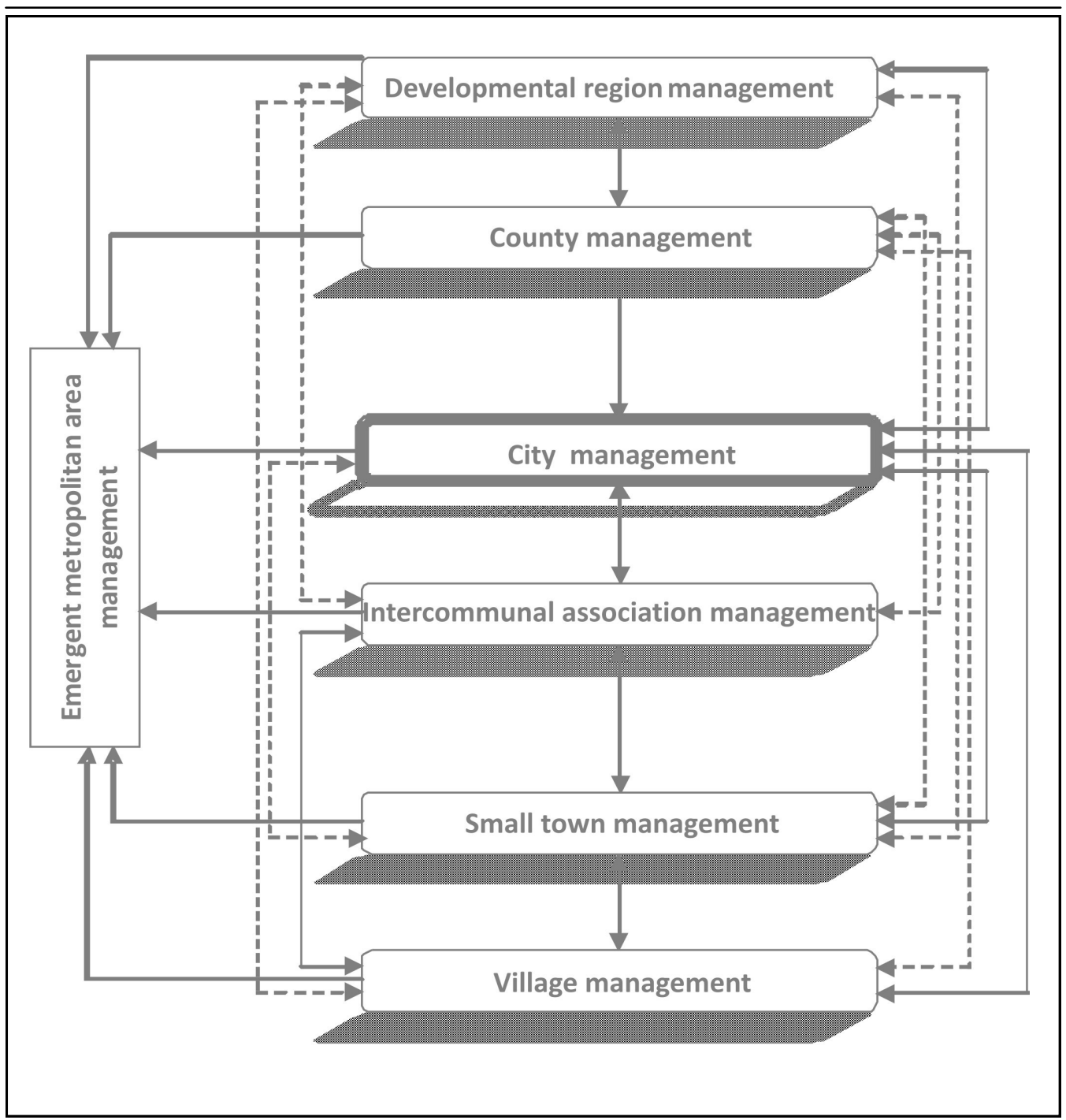

Fig. 5 - General Configuration of the Emergent Metropolitan Areas Management

obtaining advantages for their communities, following these cooperations. Their projects must be correlated to big programmes promoted at national, regional and county level. In relation to the size of the metropolitan area, some counties may be integrally included in these metropolitan areas (it is the case of llfov county, which may be entirely part of the metropolitan area Bucharest).

\section{Conclusions}

Emergent metropolitan areas, depending on each city's concrete conditions, need a specific management, especially in the case they have not met any classical phenomena of suburbanisation. Periurbanisation was almost exclusively based on the territorial effects of an 
extensive industrial development. Demographic growth and the concentration of activities which consume work power, mainly unqualified, explains why in the relationships of the city with the periurban space, the migratory flows and those of providing market with agricultural products were dominant.

The analysis upon the management systems of emergent metropolitan areas from the transition countries, where Romania is taken as a case study, shows the difficulties encountered by the restructuring process of the cooperation relationships between local communities at the level of such a territorial system. The economic boom registered between 2003 and 2008 determined a lot of problems connected to the territorial development in the interface between the city and the adjacent space. As it is the case of several cities of the world, this economic development led to an increase of the fragmentation and heterogeneousness in the metropolitan space. New economic activities, chaotically placed in metropolitan areas, produced a functional mispronunciation with the neighbourhood areas (Kanai and Ortega-Alcazar 2009).

The transition from a centralized system to a market economy does not imply only changes in the economic system, but also in social, cultural, moral and ethic systems. This is the reason why implementing management systems at the level of the crossroads of some multi-level decision systems, with an impact on trans-scale organisation of space, seems to be too early, as there is a lack of the cooperation culture between the territorial decision entities. It is considered that simple management systems are not completely matured yet, and they cannot think of the management of some supralocal spaces.

However, the metropolization process is a real phenomenon and it contours functional spaces around metropolises. This reality leads to the contouring of some structures able to ensure the harmonization of the local communities with the metropolis' interests. The remaining behind of the construction of such a structure and of the implementing of a performant management system, able to ensure the coherent development of the two territorial entities, is already reflected in the new chaotic structures from the urban sprawl, in the blockages of physical infrastructures, in the degradation of environment quality

The big enemies of the process of managing emergent metropolitan areas are the speed of changes with spatial impact, the lack of initiative of local decision factors, the increase and decrease of the real estate market, the political polarization that excludes inter-communal cooperation and the impact of interest groups.

The proposed management model for the emergent metropolitan areas starts from accepting a type of collaboration management, based on consensus and able to ensure space management during the consolidation period of these metropolitan areas. In this respect, it is important to combine multilevel management with the management of polycentrism-based development, to integrate the management on main administrative structures with sectorial management promoted on types of activities. For a good governing of emergent metropolitan areas, it is necessary to involve, on one hand, the state, which would adopt a legislation in favour of the public-private partnership, and on the other hand the civil society, whose role in this early stage is essential.

\section{Aknowledgements}

The methodology we used in this article was elaborated in some research projects, supported by National Council of Scientific Research in Higher Education: Territorial Management Based on Growth Poles Theory, Urban-Rural Interface in the Context of the Polycentric Development, 
Discontinuities Controlled Production and the Treatment of the Profound Disadvantaged Areas, Entrepreneurial Sector and its Role in Regional Disparities Attenuation.

\section{References}

ABLER, R. (1970), What Makes Cities Important, Bell Telephone Magazine.

BASSAND, M. (2004), La métropolisation de la Suisse. Lausanne, Presses Polytechniques et Universitaires Romandes.

BASSAND, M., NGOC DU, T. T., TARRADELLAS, J., CUNHA A., AND BOLAY, J.-C. (2000), Métropolisation, crise écologique et développement durable: L'eau et l'habitat précaire à Ho Chi Minh City, Vietnam, Presses Polytechniques et Universitaires Romandes (PPUR), Lausanne.

BEAUMONT, J., NICHOLLS, W. (2008), Plural Governance, Participation and Democracy in Cities, International Journal of Urban and Regional Research, 32, 1, 87-94.

BOURDEAU-LEPAGE, L. (2003), Metropolization in Central \& Eastern Europe. Unequal Chances, LEG CNRS 5118 et MSH, Université de Bourgogne, Pôle d'Economie et de Gestion, Dijon, France.

BOURDEAU-LEPAGE, L., HURIOT, J.-M. (2003), Metropolises and Global Coordination. A Historical perspective, AFSE Congress 2003, Paris (communicated paper). BRENNER, N. (2003), Metropolitan Institutional Reform and the Rescaling of State Space in Contemporary Western Europe, European Urban and Regional Studies, 10, 4, 29, DOI: $10.1177 / 09697764030104002$.

BRENNER, N. (2004), Urban governance and the production of new state spaces in Western Europe,1960-2000, Review of International Political Economy, 11, pp. 447 -488.

BURDACK, J., HERFERT, G., RUDOLPH, R. (eds.) (2005), Beiträge zur Regionalen Geographie, 61

CARLSON, T., DIERWECHTER, Y. (2007), Effects of Urban Growth Boundaries and Residential Development in Pierce County, Washington, Professional geographer, 59, 2, pp. 209-220.

CEPOIU, A., L. (2009), Rolul activităților industriale în dezvoltarea aşezărilor din spațiul metropolitan al Bucureştilor, Ed. Universitară, Bucureşti.

CERVERO, R. (1989), America's suburban centers, Unwin Hyman, Boston.

CHIRIAC, C. (2009), Emergența modelului guvernanței multi-level în România, Revista Transilvană de Ştiinte Administrative, 23, 1, pp. 5-18.

CHOAY, F. (1961), L'Urbanisme, utopies et realites, Ed. Seuil.

CKCHAN, R., HU, Y. (2004), Urban governance: a theoretical review and an empirical study, Asian Geographer, 23, 1-2, pp. 5-17.

COHEN, J, ROGERS, J. (1992), Secondary associations and democratic governance, Politics and Society, 20, 4, pp. 393-472.

DI CIOMMO, F. (2001), The economic actors and city governability: the example of urban regeneration policies in Milan, Naples and Paris, Paper presented the Conference Area - Based Initiatives in Contemporary Urban Policy, Danish Building and Urban Research, EURA, Copenhagen, 17-19 May.

DI MEO, G. (1992), Les metropoles des pays developpes, in A. Bailly, R. Ferras, D. Pumain (eds), Encyclopedie de Geographie, Ed. Economica, Paris, pp. 715-730.

ELLIOT, J., R., PERRY, M., J. (1965), Metropolizing NonmetroSpace: Population redistribution and Emergent Metropolitan Areas, 90, CDE Working paper No.96-02, Center for Demography and Ecology, University of Wisconsin-Madison.

ERDELI, G., TĂLÂNGĂ, C., POPESCU, C. (2000), Development of public services policies in Bucharest, in I. lanoş, D. Pumain, J.B.Racine (eds), Integrated Urban Systems and Sustainability of Urban Life, Ed. Tehnică, Bucharest, pp. 475-486. 
ERICKSON, R., A. (1986), Multinucleation in Metropolitan Economies, Annals of the Association of American Geographers, 76, 3, pp. 331-346.

GOTTMANN, J. (1961), Megalopolis: the urbanized North-eastern Seabord of the United States, New York, $20^{\text {th }}$ Century Fund, 810 p.

GRAVIER, J., F. (1947), Paris et le desert francais, Le Portulan, Paris.

HALL, P. (1999), Cities in civilization, Phoenix, Orion House, London.

HARVEY, D. (1989), From managerialism to entrepreneurialism - the transformation in urban governance in late capitalism, Geografiska Annaler, Series B - Human Geography, 71, pp. 3-17.

HEALEY, P. (2006), Collaborative planning: shaping places in fragmented societies, Palgrave Macmillan, Basingstoke.

HONG, W., CHAO-LIN, G. (2002), Challenges and problems: China's Urban Governance, Chinese Geographical Science, 12, 2, pp. 152-156.

HOOGHE, L., MARKS, G. (2002), Types of Multi-Level Governance, Work Paper of Department of Political Science of University of North Carolina.

IANOŞ, I. (2004), Dinamica Urbană, Ed. Tehnică, Bucureşti.

IANOŞ, I., CEPOIU, L., PINTILII, R. (2008), La fragmentation fonctionnelle du périphérique de Bucarest et le modèle d'un espace de soutien pour le développement de perspective de la capitale, Lucrările Seminarului Geografic «D. Cantemir», 27, pp. 35-48.

IANOŞ, I., PEPTENATU, D., ZAMFIR, D. (2009), Respect for environment and sustainable development, Carpathian Journal of Earth and Environmental Sciences, 4, 1, pp. 81-93.

IANOŞ, I., HUMEAU, J., B., TĂLÂNGĂ, C., BRAGHINĂ C., ANCUȚA, C., BOGDAN, L. (2010), Ethics of space and the treatment of most disadvantaged areas, Carpathian Journal of Earth and Environmental Sciences, 5, 2, pp. 203-210.

KANAI, M., ORTEGA/ALCAZAR, I. (2009), The prospects for Progressive Culture-Led Urba Regeneration in Latin America: cases from Mexico/City and Buenos Aires, International Journal of Urban and Regional Research, 33, 2, pp. 483-501.

KJÆRR A., M., (2004), Governance, Polity Press, Cambridge.

KNIELING, J. (2009), European Metropolitan Regions in global times: Challenges and Qualities, Hafen City University, Hamburg.

KRÄTKE, S. (2007), The Metropolization of the European Urban and Regional System, European Planning Studies, 15, 1, pp. 1-27.

LE GALĖS, P., VION, A. (1998), Politique culturelle et gouvernance urbaine: l'exemple de Rennes, Politiques et management public, 16, 1, pp. 5-18.

LUNCAN, A. (2010), Instrumente de planificare pentru dezvoltarea durabilă a zonelor metropolitane, PhD Thesis, Universitatea de Arhitectură şi Urbanism „Ion Mincu”, Bucureşti.

MAY, N. (1999), Districts et métropolisation: réflexions à partir de deux figures spatiales des réorganisations productives, Entre la metropolisation et le village global, Presse de I'Université de Québec, pp. 27-29.

MELO, M., BAIOCCHI, G. (2006), Deliberative democracy and local governance; towards a new agenda, International Journal of Urban and Regional Research, 30, 3, pp. 587600.

MORICONI-EBRARD, F. (1993), L'urbanisation Du Monde Depuis 1950, Economica, Paris.

MORICONI-EBRARD, F. (1994), Géopolis, Pour comparer les villes du Monde, Economica, Paris

MORICONI-EBRARD, F. (2000), De Babylone à Tokyo. Les grandes agglomérations du monde, Economica, Paris.

MORIN, R., HANLEY, J. (2004), Community economic development in a context of globalization and metropolization: a comparison of four North American cities, International 
Journal of Urban and Regional Research, 22, 2, pp. 369-383.

NEAMȚU, B. (2008), Abordări teoretice cu privire la managementul dezvoltării periurbane, Revista Transilvană de Ştiințe Administrative, 21, 1, pp. 75-98. Bucureşti.

NICOLAE, I. (2002), Suburbanismul, ca fenomen geografic în România, Ed. Meronia,

PEPTENATU, D., PINTILII, R., CEPOIU, L., DRĂGHICI, C. (2009), Polycentric development strategy - an efficient instrument in administrative decentralization, Romanian Review on Political Geography, XI, 2, pp. 85-97.

PERNIA, E., M. (1992), Southeast Asia, in R. Stren, R. White and J. Whitney (eds.), Sustainable Cities. Urbanization and the Environment in International Perspective, Westview Press, Boulder.

PIERRE, J., (2000), Debating Governance. Authority, Steering and Democracy, Oxford University Press.

POLLACK, M. (1994), Creeping competence. The expanding agenda of the European Community, Journal of European Public Policy, 14, 2, pp. 10-13.

POPESCU, I., PROFIROIU, A. (2006), Studiu comparativ privind analiza competitivității oraşelor europene, Revista Transilvană de Ştiințe Administrative, 16, pp. 92-106.

JOHNSTON, R., J., GREGORY, D., PRATT, G., WATTS, M. (2000), The Dictionary of Human Geography, Blackwell Publishing.

RHODES, R., A., W. (1997), Understanding Governance. Policy Networks, Governance, Reflexivity and Accountability, Open University Press, Buckingham.

ROUSSET-DESCAMPS, M. (2000), Gouverner les metropoles. Quelle actualite?, Villes en paralleles, 30-31, pp. 13-32.

SCARAMELLINI, G. (1996), Metropolitan Organisations: Functional and Spatial Components. A Fundamental Research Problem for Contemporary Geography in G. Dematteis and V. Guarrasi (eds), Urban Networks, Patron, Bologna.

SCOTT, J., A. (1982), Production System Dynamics and Metropolitan Development, Annals of the Association of American Geographers, 72, 2, pp. 185-200.

SCOTT, J., A. (2001), Global City-Regions: Trends, Theory, Policy, Oxford University Press, Oxford.

SCOTT, J., A. (2008), Resurgent Metropolis: Economy, Society and Urbanization in an Interconnected World, International Journal of Urban and Regional Research, 32, 3, pp. 548564.

STANBACK, T. (1991), The New Suburbanization: challenge of the central city, Oxford, Westview Press / Boulder.

STORPER, M. (1997), The Regional World: Territorial Development In A Global Economy, New-York, The Guilford Press.

TANG, F. (1981), Regional Planning In Developing Countries: The Case Of Taiwan, Republic of China, Papers of the Regional Science Association, 46, pp. 97-107.

TAKUMA, F., SASAKI, K. (2002), Spatial Structure of a Metropolitan Area with an Agricultural Hinterland, Journal of Urban Economics, 48, 2, pp. 307 - 320.

VALDÉS FOULKES, P. (2008), The management of metropolitan areas, $44^{\text {th }}$ Congress de ISOCARP, http://www.isocarp.net/Data/case studies/1127.pdf, accessed May, 8, 2011.

VELTZ, P. (1996), Mondialisation, Villes Et Territoires. L'économie D'archipel, Presses Universitaires de France, Paris.

WUST, S., BOLAY J.-C, NGOC, DU, T.T. (2002), Metropolization and the Ecological

Crisis: Precarious Settlements in Ho Chi Minh City, Vietnam, Environment \& Urbanisation, 14,

2, pp. 211-224.

http://www.metropolabrasov.ro

http://www.primariacraiova.ro

http://www.zmc.ro 
Ioan IANOŞ, Daniel PEPTENATU, Cristian DRĂGHICI, Radu Daniel PINTILII

http://www.zmi.ro

http://www.zmo.ro

HG nr.998/2008

HG nr. 1948/2008

Legea 215 din 2001

Legea 350/2001

Initial submission: 14.06.2012

Revised submission: 15.10 .2012

Final acceptance: 30.11 .2012

Correspondence: University of Bucharest, Interdisciplinary Centre for Advanced

Researches on Territorial Dynamics, 030018, 4-12, Regina Elisabeta Blv., Bucharest, Romania

E-mail: ianos50@yahoo.com 